Supporting Information for

\title{
Dendronized Arm Snowflake Polymer as a Highly Branched Scaffold for Cellular Imaging and Delivery
}

\author{
Yanhong Liu, ${ }^{a}$ Silei Bai, ${ }^{a}$ Tong $\mathrm{Wu},{ }^{a}$ Chun-Chi Chen,,${ }^{\mathrm{b}}$ Ying Liu, ${ }^{a}$ Xiangyu Chao ${ }^{\mathrm{a}}$ and Yugang Bai ${ }^{\mathrm{a} *}$ \\ a State Key Laboratory of Chem-/Bio-Sensing and Chemometrics, School of Chemistry and Chemical Engineering, \\ Hunan University, Changsha, Hunan 410082, China \\ ${ }^{\mathrm{b}}$ State Key Laboratory of Biocatalysis and Enzyme Engineering, School of Life Sciences, Hubei University, Wuhan, \\ Hubei 430062, China
}

\section{Table of Contents}

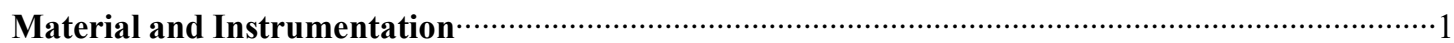

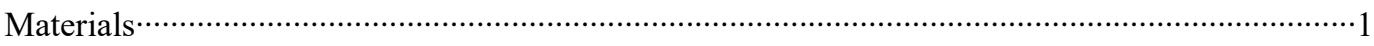

Instruments

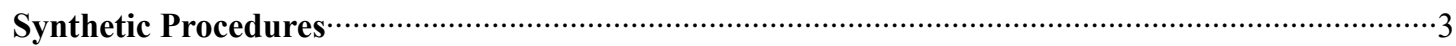

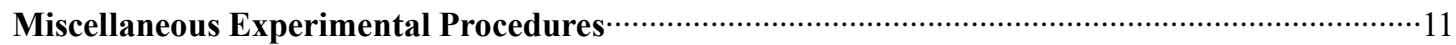

Characterizations

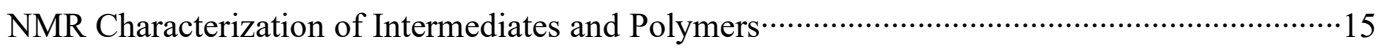

Transmission Electron Microscopy …………………….................................................. 19

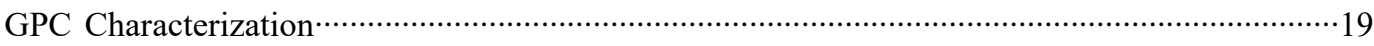

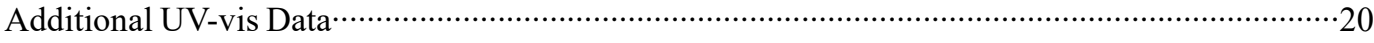

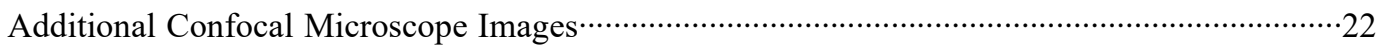



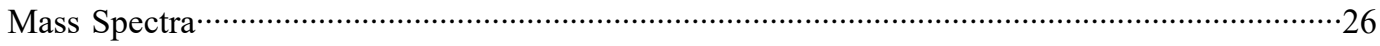

Summary Tables 


\section{Material and Instrumentation}

\section{$\underline{\text { Materials }}$}

All solvents and reagents were purchased from Adamas Reagent Ltd. (Shanghai), Macklin Biochemical Co., Ltd. (Shanghai) or Leyan (Haoyuan ChemExpress). LysoTracker Red was purchased from Beyotime Biotechnology (Shanghai). Reagents were used without further purification unless otherwise noted. Water was purified by a MilliQ water purification system, and all the other solvents were dried and stored over activated $4 \AA$ molecular sieves.

\section{$\underline{\text { Instruments }}$}

Nuclear Magnetic Resonance (NMR). NMR spectra were recorded using a Bruker Avance II $400 \mathrm{MHz}$ spectrometer in the NMR Laboratory, Institute of Chemical Biology and Nanomedicine, Hunan University. The data was processed in MestReNova 6.1 and aligned/annotated in Adobe Illustrator CC.

Mass Spectrometry. Electrospray ionization (ESI) mass spectral analyses were conducted at the Mass Spectrometry Laboratory, School of Chemical Engineering, Dalian University of Technology, using an Agilent ESI mass spectrometer instrument.

Analytical Gel Permeation Chromatography (GPC). GPC experiments were performed on a Waters-Wyatt hybrid system equipped with a Waters 515 isocratic pump, a Waters 2414 refractive index detector, and a miniDAWN TREOS II multi-angle laser light scattering detector (MALLS, Wyatt Technology, CA). Separations were performed at $50{ }^{\circ} \mathrm{C}$ using PLgel PL1110-6530/6540/6550 columns (Agilent) and DMF containing 0.1 M LiBr as the mobile phase. The detection wavelength of TREOS was set at 658 nm. The MALLS detector was calibrated using pure toluene and used for the determination of absolute molecular weights. The molecular weight of all linear 
polymers was determined based on the $d \mathrm{n} / d \mathrm{c}$ value of each sample calculated offline using the ASTRA 7 software (Wyatt). The obtained data points were imported into OriginPro (version 9.5), plotted, and saved as vector image files (*.eps) for coloring and annotation in Adobe Illustrator CC.

Transmission Electron Microscopy (TEM). TEM experiments were conducted on a JEM-2100 Plus transmission electron microscope. For sample preparation, $20 \mu \mathrm{L}$ of DASP $(200 \mu \mathrm{g} / \mathrm{mL})$ was added on the copper grid, dried at room temperature overnight, and used directly for imaging.

UV-vis Spectroscopy. UV-vis measurements were carried out on a Cary 60 UV-vis spectrometer (Agilent Technologies). The obtained data points were imported into OriginPro (version 9.5), plotted and smoothed, and saved as vector image files (*.eps) for coloring and annotation in Adobe Illustrator CC.

Fluorescence Spectroscopy. Fluorescence intensities were measured by a HITACHI F-7000 fluorescence spectrophotometer. The obtained data points were imported into GraphPad Prism 6, plotted, and saved as vector image files (*.eps) for coloring and annotation in Adobe Illustrator CC.

Confocal Microscopy. Fluorescence microscope images were acquired using a Nikon Eclipse Ti2-E Laser Confocal Microscope. For TPE fluorescence, wavelength was set at $405 \mathrm{~nm}$ for excitation, and $482 \mathrm{~nm}$ filter was used for emission. For imaging of LysoTracker Red, wavelengths were set at $561 \mathrm{~nm}$ for excitation, and $595 \mathrm{~nm}$ filter was used for emission. For FRET fluorescence, emission wavelengths were set at $545 \mathrm{~nm}$ for fluorescein moieties, $595 \mathrm{~nm}$ filter was used for PSP dye. 


\section{Synthetic Procedures}

\section{Synthesis of the $3^{\text {rd }}$ Generation PGD Monomer}

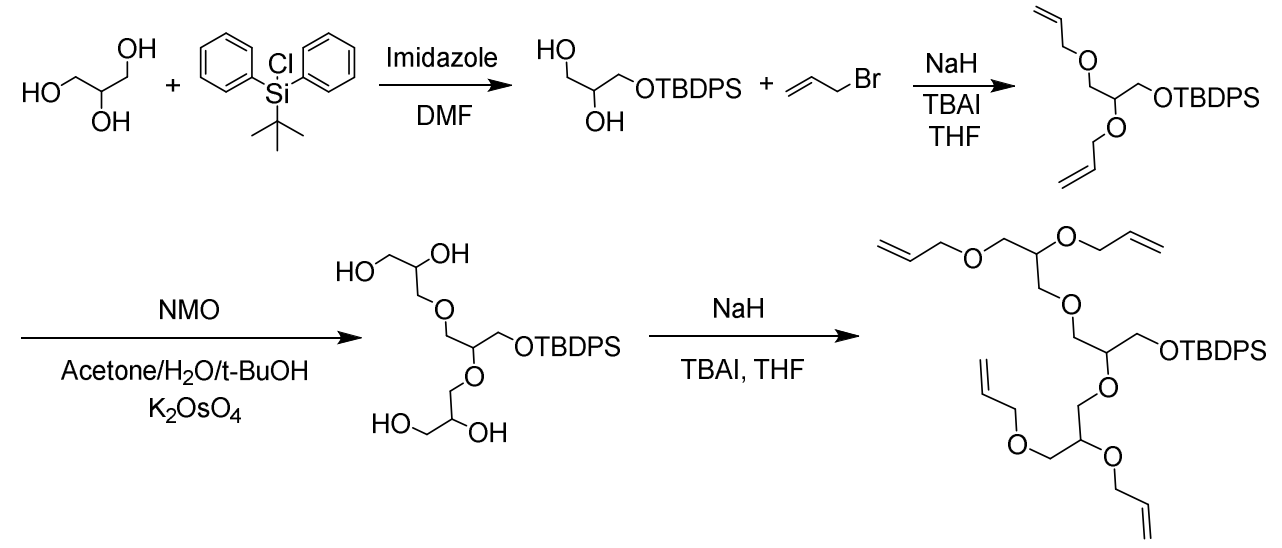<smiles>CC1(C)OCC(COCC(COCC(COCC(COCC2COC(C)(C)O2)OCC2COC(C)(C)O2)OCC2COC(C)(C)O2)OCC2COC(C)(C)O2)O1</smiles><smiles>CC1(C)OCC(COCC(COCC(C[Se]OC(COCC2COC(C)(C)O2)COCC2COC(C)(C)O2)OCC2COC(C)(C)O2)OCC2COC(C)(C)O2)O1</smiles><smiles>CC1(C)OCC(COCC(COCC(COCC(COCC2COC(C)(C)O2)OCC2COC(C)(C)O2)OCC2COC(C)(C)O2)OCC2COC(C)(C)O2)O1</smiles>

This monomer was synthesized following a reported procedure (Chem. Commun., 2016, 
$52,3781)$. All characterization results of the product were consistent with the previously reported data.

\section{Synthesis of the Crosslinker}<smiles>O=C(c1ccc(O)cc1)c1ccc(C(c2ccccc2)c2ccc(O)cc2)c(C(c2ccccc2)c2ccccc2)c1</smiles>

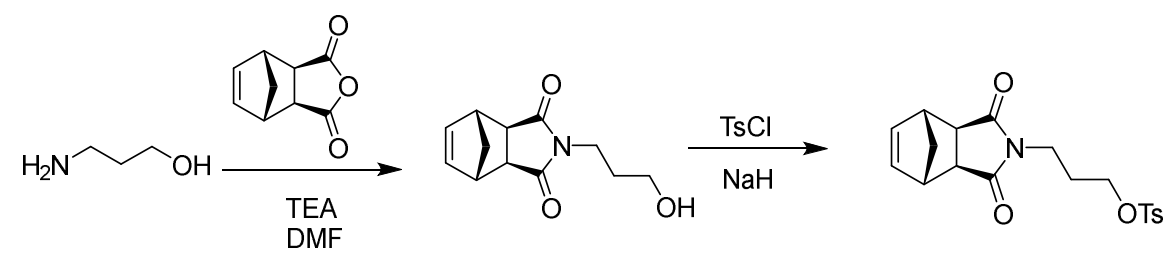



Synthesis of dihydroxyl tetraphenylethylene

This compound was synthesized following a reported procedure (Chem. Commun., 2017, 53, 12676). All characterization results of the product were consistent with the previously reported data.

Synthesis of $N$-hydroxypropyl norbornenedicarboximide

This compound was synthesized following a reported procedure (Chem. Sci., 2012, 3, 581). All characterization results of the product were consistent with the previously reported data.

\section{Synthesis of crosslinker 3}

A round bottom flask charged with $N$-hydroxypropyl norbornenedicarboximide (10.0 g, 45.2 mmol, 1 eq.), $p$-toluenesulfonyl chloride (12.9 g, 67.8 mmol, 1.5 eq.), $\mathrm{NaH}$ (1.30 g, $54.2 \mathrm{mmol}, 1.2$ eq.) and THF (50 mL) was stirred overnight at room temperature, and the reaction was monitored by TLC. Upon completion of the reaction, the solvent was removed under reduced pressure, and the residue was partitioned between ethyl 
acetate and water. The isolated organic layer was further washed, dried and evaporated to obtain a solid, which was purified via column chromatography (EtOAc/PE) to obtain the pure tosylated product. This pale-yellow product ( $8.70 \mathrm{~g}, 23.2 \mathrm{mmol}, 2.4$ eq.) was added to a 100-mL round bottom flask, followed by the addition of dihydroxyl tetraphenylethylene (3.52 g, $9.65 \mathrm{mmol}, 1$ eq.), $\mathrm{K}_{2} \mathrm{CO}_{3}$ (7.69 g, $55.6 \mathrm{mmol}, 2.4$ eq.) and KI (0.770 g, $4.63 \mathrm{mmol}, 0.2$ eq.). The mixture was refluxed in acetone $(50 \mathrm{~mL})$ overnight, and the reaction was quenched by adding cold water $(30 \mathrm{~mL})$. The resulting mixture was extracted with $\mathrm{CH}_{2} \mathrm{Cl}_{2}(50 \mathrm{~mL} \times 3)$, the combined organic extracts were washed 3 times with brine, dried over anhydrous $\mathrm{Na}_{2} \mathrm{SO}_{4}$ and concentrated to dryness in vacuo. The residue was purified by flash column chromatography (PE/EA ,5:1-2:1) to obtain the product $(3.1 \mathrm{~g}, 25 \%)$ as a pale-yellow solid. ${ }^{1} \mathrm{H} \mathrm{NMR}\left(400 \mathrm{MHz}, \mathrm{CDCl}_{3}\right)$ : $\delta 7.06(m, 10 \mathrm{H}), 6.88(d, J=7.9 \mathrm{~Hz}, 4 \mathrm{H}), 6.59(d, J=7.9 \mathrm{~Hz}, 4 \mathrm{H}), 6.28(s, 4 \mathrm{H}), 3.90$ $(t, J=5.4 \mathrm{~Hz}, 4 \mathrm{H}), 3.65(t, J=6.8 \mathrm{~Hz}, 4 \mathrm{H}), 3.26(s, 4 \mathrm{H}), 2.66(s, 4 \mathrm{H}), 2.01(m, 4 \mathrm{H})$, $1.50(d, J=9.7 \mathrm{~Hz}, 2 \mathrm{H}), 1.22(d, J=9.7 \mathrm{~Hz}, 2 \mathrm{H}) .{ }^{13} \mathrm{C} \mathrm{NMR}\left(101 \mathrm{MHz}, \mathrm{CDCl}_{3}\right): \delta$ 177.92, 157.10, 144.21, 139.66, 137.84, 136.53, 132.51, 131.37, 127.66, 126.18, 113.58, $65.58,47.84,45.18,42.82,36.26,27.65$. High resolution ESI-MS $(\mathrm{m} / \mathrm{z})$ : Calculated for $\mathrm{C}_{50} \mathrm{H}_{47} \mathrm{~N}_{2} \mathrm{O}_{6}{ }^{+} \quad\left([\mathrm{M}+\mathrm{H}]^{+}\right): \quad 771.3429, \quad \mathrm{C}_{50} \mathrm{H}_{50} \mathrm{~N}_{3} \mathrm{O}_{6}{ }^{+} \quad\left(\left[\mathrm{M}+\mathrm{NH}_{4}\right]^{+}\right): \quad 788.3694$, $\mathrm{C}_{50} \mathrm{H}_{46} \mathrm{~N}_{2} \mathrm{O}_{6} \mathrm{Na}^{+}\left([\mathrm{M}+\mathrm{Na}]^{+}\right)$: 793.3248; found 771.3433, 788.3710, 793.3268.

\section{Representative Protocol of the Synthesis of DASP 4}

The PGD monomer (30.0 mg, $33.4 \mu \mathrm{mol}, 50$ eq.) was added to a $7-\mathrm{mL}$ glass vial, and $\mathrm{CH}_{2} \mathrm{Cl}_{2}(1.5 \mathrm{~mL})$ was added to dissolve the compound. Grubbs $3^{\text {rd }}$ generation catalyst (26.7 $\mu \mathrm{L}, 25.0 \mathrm{mM}$ in DCM, $0.667 \mu \mathrm{mol}, 1$ eq.) was quickly added to the solution with vigorous stirring. The resulting solution was stirred at room temperature for $15 \mathrm{~min}$ before crosslinker 3 (in DCM, $20.6 \mathrm{mg}, 26.7 \mu \mathrm{mol}, 40$ eq.) was added to the mixture. The stirring was continued for $4 \mathrm{~h}$, and ethyl vinyl ether (200 $\mu \mathrm{L}$, excess) was added to quench the polymerization. DCM and excess ethyl vinyl ether were removed in vacuo, and the residue was purified by dissolving the polymer in DCM, precipitating it in diethyl ether and $n$-hexane, and isolating the solid by centrifugation. The precipitates 
were washed by diethyl ether for additional 2 times and dried under reduced pressure obtain DASP 4 as a light-yellow solid (45 mg, 89\%, ca. $750 \mathrm{kDa}$ ). DASPs of other sizes were synthesized using the same procedure with different monomer/crosslinker to initiator ratios.

Note: the star polymer synthesis has inevitable randomness. Molecular weight obtained from repeated experiment can vary $( \pm 15 \%)$ to some extent and dispersity ranges from 1.2 to 1.4 .

\section{Synthesis of the Water-soluble DASP Scaffold, 5}

The ketal-protected DASP 4 (40 mg) was dissolved in $\mathrm{H}_{2} \mathrm{O}(2 \mathrm{~mL})$ in a 20-mL vial, and TFA $(0.5 \mathrm{~mL})$ was added. The reaction vial was capped and stirred at room temperature for $4 \mathrm{~h}$. The solution was directly transferred into a dialysis bag $(\mathrm{MWCO}=3 \mathrm{kDa})$ and dialyzed against water for $1 \mathrm{~d}$. The resulting solution of $\mathbf{5}$ was purified by passing the solution through a PES syringe filter $(0.45 \mu \mathrm{m})$. The obtained product solution (containing $25 \mathrm{mg}$ of 5) was directly used in the following studies.

Note: the concentration of $\mathbf{5}$ was measured by taking a small amount of solution, lyophilizing, and weighing the resulting solid, because 5 does not redissolve in water very well after lyophilization.

Synthesis of polyPGD. The PGD monomer $(30.0 \mathrm{mg}, 33.4 \mu \mathrm{mol}, 50$ eq.) was added to a 20-mL glass vial, and $\mathrm{CH}_{2} \mathrm{Cl}_{2}(1.5 \mathrm{~mL})$ was added to dissolve the solid. Grubbs $3^{\text {rd }}$ generation catalyst $(26.7 \mu \mathrm{L}, 25.0 \mathrm{mM}$ in DCM, $0.667 \mu \mathrm{mol}, 1$ eq.) was quickly added to the solution with vigorous stirring. The reaction was allowed to stir for $15 \mathrm{~min}$ before ethyl vinyl ether (200 $\mu \mathrm{L}$, excess) was added to quench the polymerization. DCM and excess ethyl vinyl ether were removed in vacuo, and the residue was purified by dissolving the polymer in DCM, precipitating it in diethyl ether and $n$-hexane, and isolating the solid by centrifugation. The precipitates were washed by diethyl ether for additional 2 times and dried under reduced pressure obtain the ketal-protected polyPGD as a greenish grey solid (20 mg). The ketal-protected polyPGD $(20 \mathrm{mg})$ was dissolved 
in $\mathrm{H}_{2} \mathrm{O}(1 \mathrm{~mL})$ in a $7-\mathrm{mL}$ vial, and TFA $(0.2 \mathrm{~mL})$ was added. The reaction vial was capped and stirred at room temperature for $2 \mathrm{~h}$. The solution was directly transferred into a dialysis bag $(\mathrm{MWCO}=1 \mathrm{kDa})$ and dialyzed against water for $1 \mathrm{~d}$. The resulting solution of polyPGD was purified by passing the solution through a PES syringe filter $(0.45 \mu \mathrm{m})$. The obtained product solution was lyophilized to give the product in solid form.

\section{Synthesis of the Fluorescein-Labeled DASP Scaffold (FL-DASP)}

The synthesis of FL-DASP scaffold was similar to the above-mentioned procedure for DASP. The only difference in the procedure was the use of 5(6)-carboxyfluorescein monomer (NB-FL) in the polymerization stage. This monomer was synthesized following our reported procedure (ACS Materials Lett., 2020, 2, 89). Specifically, in the very beginning of the polymerization, only the PGD monomer 1 (40.0 mg, 44.5 $\mu \mathrm{mol}, 50$ eq.) was dissolved in $1.8 \mathrm{~mL}$ of DCM, followed by the addition of Grubbs $3^{\text {rd }}$ generation catalyst $2(35.6 \mu \mathrm{L}, 25.0 \mathrm{mM}$ in chloroform, 1 eq.). After $2 \mathrm{~min}, \mathbf{N B}-\mathbf{F L}$ monomer $(0.640 \mathrm{mg}, 0.890 \mu \mathrm{mol}, 1$ eq. $)$ in $\mathrm{DCM}(0.2 \mathrm{~mL})$ was added to the polymerizing mixture, and the crosslinker 3 (27.4 mg, $35.6 \mu \mathrm{mol}, 40$ eq.) after another $15 \mathrm{~min}$. The rest of the procedure was the same.

\section{Synthesis of the TEG Monomer}

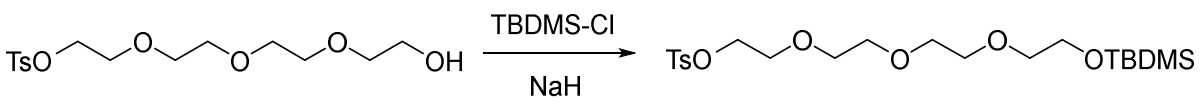

Synthesis of tetraethylene glycol monosilyl ether (TsO-TEG-OTBDMS): The monotosylated TEG (5.00 g, $14.4 \mathrm{mmol}, 1$ eq.) and TBDMS-Cl (4.33 g, 28.7 mmol, 2 eq.) were added to dry THF $(30 \mathrm{~mL})$ in a round bottom flask, and $\mathrm{NaH}(0.410 \mathrm{~g}, 17.2 \mathrm{mmol}$, 1.2 eq.) was added to the mixture slowly at $0^{\circ} \mathrm{C}$. After stirring the mixture overnight at room temperature, the reaction was quenched by adding water $(50 \mathrm{~mL})$. The resulting mixture was extracted with $\mathrm{CH}_{2} \mathrm{Cl}_{2}(50 \mathrm{~mL} \times 3)$, and the combined organic extracts was washed 3 times with brine, dried over anhydrous $\mathrm{Na}_{2} \mathrm{SO}_{4}$ before it was concentrated to dryness in vacuo. The residue was purified by flash column chromatography 
(PE/EA ,4:1-2:1) to obtain the pure product as a colorless oil (7.5 g, 85\%). ${ }^{1} \mathrm{H}$ NMR (400 MHz, $\left.\mathrm{CDCl}_{3}\right): \delta 7.79(d, J=7.6 \mathrm{~Hz}, 2 \mathrm{H}), 7.33$ (d, J=7.6 Hz, 2H), 4.15 (broad, 2H), 3.75 (broad $t, J=4.2 \mathrm{~Hz}, 2 \mathrm{H}), 3.70-3.52(m, 12 \mathrm{H}), 2.44(s, 3 \mathrm{H}), 0.88(s, 9 \mathrm{H}), 0.05$ $(s, 6 \mathrm{H}) .{ }^{13} \mathrm{C}$ NMR $\left(100 \mathrm{MHz}, \mathrm{CDCl}_{3}\right): \delta 144.75,133.06,129.80,127.98,72.67,70.77$, 70.71, 70.68, 70.55, 69.22, 68.68, 62.71, 25.93, 21.63, 18.37, -5.26. High resolution ESI-MS (m/z): Calculated for $\mathrm{C}_{21} \mathrm{H}_{39} \mathrm{O}_{7} \mathrm{SSi}^{+}\left([\mathrm{M}+\mathrm{H}]^{+}\right)$: 463.2180; $\mathrm{C}_{21} \mathrm{H}_{42} \mathrm{O}_{7} \mathrm{NSSi}^{+}$ $\left(\left[\mathrm{M}+\mathrm{NH}_{4}\right]^{+}\right): 480.2446$; found $463.2187,480.2462$.

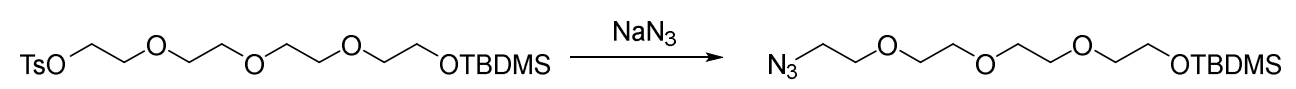
Synthesis of azido tetraethylene glycol (N-TEG-OTBDMS): A flask was added TsOTEG-OTBDMS (5.50 g, 11.9 mmol, 1 eq.), $\mathrm{NaN}_{3}$ (2.32 g, 35.7 mmol, 3 eq.) and DMF $(20 \mathrm{~mL})$, and the mixture was stirred overnight at $90^{\circ} \mathrm{C}$. The mixture was cooled, added water $(50 \mathrm{~mL})$, and extracted with $\mathrm{CH}_{2} \mathrm{Cl}_{2}(50 \mathrm{~mL} \times 3)$. The organic layers were combined and washed 3 times with brine before dried over anhydrous $\mathrm{Na}_{2} \mathrm{SO}_{4}$. The solution was concentrated to dryness in vacuo, and the residue was purified by flash chromatography (PE:EA, 3:1) to obtain a colorless oil (2.8 g, 71\%). ${ }^{1} \mathrm{H}$ NMR (400 MHz, $\left.\mathrm{CDCl}_{3}\right): \delta 3.76$ (broad, 2H), 3.60-3.71 (m, 10H), 3.56 (broad, 2H), 3.38 (broad, 2H), $0.88(s, 9 \mathrm{H}), 0.06(s, 6 \mathrm{H}) .{ }^{13} \mathrm{C} \mathrm{NMR}\left(100 \mathrm{MHz}, \mathrm{CDCl}_{3}\right): \delta 72.67,70.74$ (3 overlapping peaks), 70.66, 70.03, 62.71, 50.70, 25.93, 18.37, -5.27. High resolution ESI-MS (m/z): Calculated for $\mathrm{C}_{14} \mathrm{H}_{32} \mathrm{~N}_{3} \mathrm{O}_{4} \mathrm{Si}^{+}\left([\mathrm{M}+\mathrm{H}]^{+}\right): 334.2157 ; \mathrm{C}_{14} \mathrm{H}_{35} \mathrm{~N}_{4} \mathrm{O}_{4} \mathrm{Si}^{+}\left(\left[\mathrm{M}+\mathrm{NH}_{4}\right]^{+}\right)$: 351.2422; found 334.2166, 351.2433.

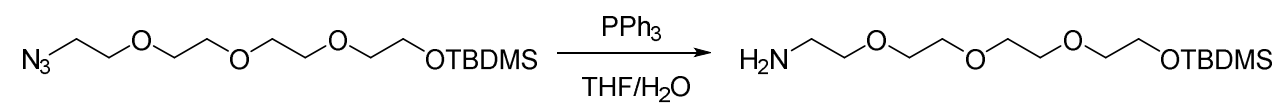

Synthesis of amino tetraethylene glycol ( $\left.\mathrm{H}_{2} \mathrm{~N}-\mathrm{TEG}-\mathrm{OTBDMS}\right)$ : A flask was added $\mathrm{N}_{3}-$ TEG-OTBDMS (2.80 g, 8.40 mmol, 1 eq.), $\mathrm{PPh}_{3}$ (3.30 g, 12.6 mmol, 1.5 eq.), THF (20 $\mathrm{mL})$, and water $(2 \mathrm{~mL})$, and the mixture was stirred overnight at room temperature. The resulting mixture was dried over anhydrous $\mathrm{Na}_{2} \mathrm{SO}_{4}$, concentrated to dryness in vacuo, and purified by flash chromatography (silica, $\mathrm{CH}_{2} \mathrm{Cl}_{2}: \mathrm{CH}_{3} \mathrm{OH}, 1: 1-1: 4$ ) to obtain a colorless oil (1.7 g, 65\%). ${ }^{1} \mathrm{H}$ NMR (400 MHz, $\left.\mathrm{CDCl}_{3}\right)$ : $\delta 3.76$ (broad, 2H), 3.65 (m, 
8H), 3.48-3.58 (m, 4H), 2.87 (broad, 2H), 2.19 (broad, 2H), $0.89(s, 9 \mathrm{H}), 0.06(s, 6 \mathrm{H})$. ${ }^{13} \mathrm{C} \mathrm{NMR}\left(100 \mathrm{MHz}, \mathrm{CDCl}_{3}\right): \delta 73.10,72.66,70.71,70.63,70.56,70.29,62.71,41.63$, $25.92,18.35,-5.28$.

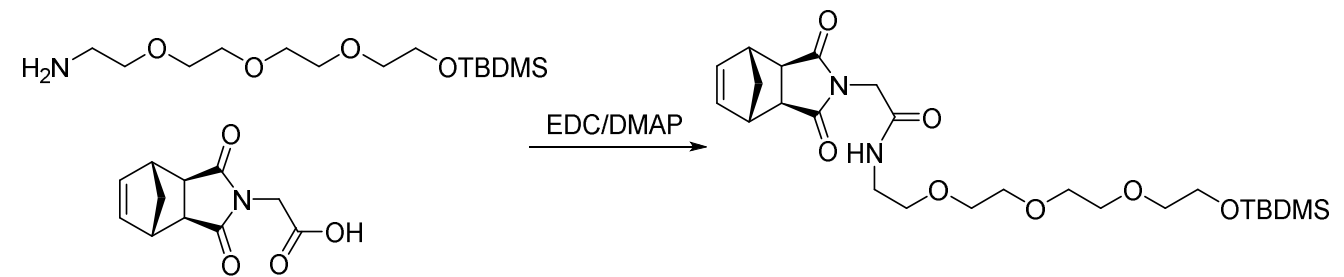

Synthesis of the TEG monomer: $\mathrm{H}_{2} \mathrm{~N}-\mathrm{TEG}-\mathrm{OTBDMS}$ (1.70 g, $5.53 \mathrm{mmol}, 1$ eq.) and $N$-glycine exo-norbornenedicarboximide $(1.35 \mathrm{~g}, 6.08 \mathrm{mmol}, 1.1$ eq. $)$ was mixed in $\operatorname{DCM}(20 \mathrm{~mL})$. The solution was added $\mathrm{EDC} \cdot \mathrm{HCl}(2.12 \mathrm{~g}, 11.1 \mathrm{mmol}, 2$ eq. $)$ and DMAP (67.0 $\mathrm{mg}, 0.550 \mathrm{mmol}, 0.1$ eq.). After stirring overnight at room temperature, the resulting mixture was partitioned between DCM and water $(50 \mathrm{~mL})$, and the aqueous phase was further extracted by DCM $(50 \mathrm{~mL})$ twice. The combined organic extracts were washed 3 times with brine, dried over anhydrous $\mathrm{Na}_{2} \mathrm{SO}_{4}$ and concentrated to dryness in vacuo. The residue was purified by flash chromatography (silica, PE: EA, 2:1-1:2) to obtain a colorless oil $(2.5 \mathrm{~g}, 82 \%) .{ }^{1} \mathrm{H}$ NMR $\left(400 \mathrm{MHz}, \mathrm{CDCl}_{3}\right): \delta 6.60$ (broad $s, 1 \mathrm{H}), 6.27(s, 2 \mathrm{H}), 4.12(s, 2 \mathrm{H}), 3.75$ (broad t, $J=4.8 \mathrm{~Hz}, 2 \mathrm{H}), 3.58-3.69,(m$, $8 \mathrm{H}), 3.51-3.57(m, 4 \mathrm{H}), 3.39-3.46(m, 2 \mathrm{H}), 3.29(s, 2 \mathrm{H}), 2.71(s, 2 \mathrm{H}), 1.83(d, J=9.7$ $\mathrm{Hz}, 1 \mathrm{H}), 1.50(d, J=9.7 \mathrm{~Hz}, 1 \mathrm{H}), 0.87(s, 9 \mathrm{H}), 0.04(s, 6 \mathrm{H}) .{ }^{13} \mathrm{C}$ NMR $(101 \mathrm{MHz}$, $\left.\mathrm{CDCl}_{3}\right): \delta 177.50,165.57,138.00,72.68,70.70,70.55,70.53,70.30,69.62,62.76$, 48.04, 45.44, 43.00, 40.78, 39.63, 25.94, 18.39, -5.27. High resolution ESI-MS (m/z): Calculated for $\mathrm{C}_{25} \mathrm{H}_{43} \mathrm{~N}_{2} \mathrm{O}_{7} \mathrm{Si}^{+}\left([\mathrm{M}+\mathrm{H}]^{+}\right)$511.2834, found 511.2846.

Synthesis of the LASP Scaffold. In a 7-mL vial containing $0.5 \mathrm{~mL}$ DCM was added the TEG monomer (15.0 mg, $29.4 \mu \mathrm{mol}, 50$ eq.), and with rapid stirring, Grubbs thirdgeneration catalyst $(23.5 \mu \mathrm{L}, 25.0 \mathrm{mM}$ in DCM, 1 eq.) was quickly added. The reaction was allowed to proceed for $15 \mathrm{~min}$ before crosslinker 3 (11.3 mg, $14.7 \mu \mathrm{mol}, 25$ eq.) was added. The stirring was continued for $4 \mathrm{~h}$. Ethyl vinyl ether (200 $\mu \mathrm{L}$, excess) was added to quench the polymerization. DCM and excess ethyl vinyl ether were removed 
in vacuo, and the residue was re-dissolved in a small amount of DCM and precipitated into a mixture of diethyl ether and $\mathrm{n}$-hexane in a $15-\mathrm{mL}$ centrifuge tube. The precipitates were isolated by centrifugation, and was further purified by repeated dissolution and ether/n-hexane precipitation. TBDMS-protected LASP was eventually obtained as a light-yellow solid (21 mg, 80\%).

TBDMS-protected LASP (30 mg) was dissolved in DMF $(1 \mathrm{~mL})$ in a 7-mL vial, and a large excess of TBAF solution was added. The vial was capped, and the reaction was stirred at room temperature for $8 \mathrm{~h}$. The solution was dialyzed against water for $2 \mathrm{~d}$, and was filtered through a disk syringe filter (PES, $0.45 \mu \mathrm{m}) .15 \mathrm{mg}$ of product was obtained. 


\section{Miscellaneous Experimental Procedures}

Nile Red Encapsulation. Solutions of DASP 5, polyPGD, PGD monomer (ketal removed) and LASP were prepared into groups of different concentrations. Excess Nile Red was added to the solutions $(1 \mathrm{~mL})$, and the resulting suspensions were stirred overnight at $1000 \mathrm{rpm}$. The suspensions were transferred into a $1.5 \mathrm{~mL}$ centrifuge tube, and not-encapsulated dye were removed using centrifugation (6000 rpm, $10 \mathrm{~min}$ ). The supernatant was transferred into cuvettes and the UV absorptions of the solution were measured and compared.

Photostability Studies. Stock solutions of FL-DASP and fluorescein in PBS were diluted to reach the same absorptivity at $490 \mathrm{~nm}$ (approximately $2 \mathrm{nM}$ for fluorescein moiety). $3 \mathrm{~mL}$ of each solution was transferred into transparent glass vials, and was irradiated using a laser light source $(454 \mathrm{~nm}, 20 \mathrm{~W})$ for $12 \mathrm{~h}$, during which time the emission of the solutions were measured every $2 \mathrm{~h}\left(E_{\mathrm{x}}=490 \mathrm{~nm} ; E_{\mathrm{m}}=545 \mathrm{~nm}\right.$ (FLDASP) or $525 \mathrm{~nm}$ (fluorescein)).

Cellular Uptake Study Using Confocal Microscopy. 300,000 HeLa cells were seeded into the wells of a glass-bottom cell culture dish. For each well, the final volume was 1 $\mathrm{mL}$. The cells were incubated for 18 to $24 \mathrm{~h}$ to attach to the plate. Stock solution of DASP $5(6 \mathrm{mg} / \mathrm{mL}, 200 \mu \mathrm{L})$ was added to the cell culture medium so that the final concentration of $\mathbf{5}$ in the culture medium was $1 \mathrm{mg} / \mathrm{mL}$. The cells were cultured in an incubator at $37^{\circ} \mathrm{C}$ with $5 \% \mathrm{CO}_{2}$ atmosphere for $24 \mathrm{~h}$. The cell culture medium was removed, and the cells were washed with PBS (1 mL each time, 4-5 times). Lysotracker Red was added to stain the cells, and the cells were incubated in a $5 \% \mathrm{CO}_{2}$ atmosphere at $37^{\circ} \mathrm{C}$ for another $0.5 \mathrm{~h}$ before they were wash again with PBS ( $1 \mathrm{~mL}$ each time, $4-5$ times). Paraformaldehyde fixation solution $(4 \%, 1 \mathrm{~mL})$ was added, and the cells were incubated at 20 to $25^{\circ} \mathrm{C}$ for $15 \mathrm{~min}$. Cells were washed with PBS $(1 \mathrm{~mL} \times 3,2-5 \mathrm{~min}$ each time). Finally, PBS (500 $\mu \mathrm{L})$ was added, and the cells were imaged under a confocal microscope. 
Cellular Uptake Study Using Flow Cytometry. The inhibition effects of various endocytic inhibitors were explored for the internalization of FL-DASP. Briefly, HeLa cells were respectively pre-incubated with media containing wortmannin $(10 \mu \mathrm{g} / \mathrm{mL})$, genistein $(100 \mu \mathrm{g} / \mathrm{mL})$, or chlorpromazine $(10 \mu \mathrm{g} / \mathrm{mL})$ for $30 \mathrm{~min}$ at $37^{\circ} \mathrm{C}$, followed by incubation with FL-DASP for another $12 \mathrm{~h}$ at $37^{\circ} \mathrm{C}$. Cell sample that was not preincubated with any inhibitor was used as positive control (PC), and cell sample that was not incubated with FL-DASP nor any inhibitor was used as negative control (NC). After incubation, the samples were loaded on a flow cytometer (10,000 cells) and quantified. Inhibitory effects were shown as percentage uptake level of positive control group, calculated as:

Cell Uptake Level of Treated Sample $=\left(M F I_{\text {Treated_Sample }}-M F I_{N C}\right) /\left(M F I_{P C}-M F I_{N C}\right)$

where MFI was mean fluorescence intensity measured by flow cytometry.

Note: the net inhibitory effect was not high, because the incubation time was long (12 $h$, so that enough FL-DASP could enter the cells to give reasonable fluorescence signal, as its cell uptake was inherently slow), but the inhibitors' effect diminished in only several hours. However, significant differences could be observed for groups treated with different inhibitors.

Neutral Red Uptake Cytotoxicity Assay. The cells were treated with DASP 5 in DMEM at concentrations from 1024 to $8 \mu \mathrm{g} / \mathrm{mL}$ (final) in a 96-well plate, and the incubation was allowed for $24 \mathrm{~h}$. Cells without DASP treatment were used as control. After incubation, the medium was removed and the cells were wash twice with PBS, then $200 \mu \mathrm{L}$ of Neutral Red staining solution was added into each well. The cells were incubated for another $2 \mathrm{~h}$ at $37^{\circ} \mathrm{C}$. The staining solution was removed from the wells, and PBS was used to wash the cells twice. $100 \mu \mathrm{L}$ of cell lysate was added to each well, and the plate was placed on a shaker for $20 \mathrm{~min}$. The cell viability was measured by reading the absorbance of Neutral Red dye at $540 \mathrm{~nm}$ on the plate reader. The cell 
viability value was calculated as: Viability $(\%)=[$ Abs of the treated sample $(540 \mathrm{~nm})]$ / [Abs of the control $(540 \mathrm{~nm})] \times 100 \%$.

Prolonged Cellular Imaging. Overnight culture of HeLa cells was added DASP 5 (final concentration $=1 \mathrm{mg} / \mathrm{mL}$ ) after $12 \mathrm{~h}$ of attachment, and the cells were incubated with 5 for 24 h. Used as the first passage, a portion of the cells were taken out, washed with PBS $(1 \mathrm{~mL} \times 5)$, and added 4\% paraformaldehyde fixation solution $(1 \mathrm{~mL})$. Cells were fixed at 20 to $25^{\circ} \mathrm{C}$ for $15 \mathrm{~min}$, washed with PBS ( $1 \mathrm{~mL} \times 3,2-5$ in each time), and re-added PBS $(500 \mu \mathrm{L})$ before they were imaged under a confocal microscope. Imaging of later cell passages were performed in a similar manner.

The quantification of the effectiveness of long-term cellular imaging was achieved using flow cytometry. A portion of cells of the desired passage was washed with PBS $(1 \mathrm{~mL} \times 5)$, and digested with trypsin. The cells were transferred to a $1-\mathrm{mL}$ centrifuge tube, and were centrifuged at a speed of $5000 \mathrm{rpm}$. The supernatant was removed, and $4 \%$ paraformaldehyde fixation solution $(500 \mu \mathrm{L})$ was added. The fixed cells were analyzed on a flow cytometer, and cells without the treatment of $\mathbf{5}$ was used as the control. In each analysis, 10,000 cells were counted.

Intracellular Delivery of Chloramphenicol. RAW264.7 cells were seeded in a 96well plate $(10,000$ cells per well) and allowed to adhere for $12 \mathrm{~h}$. S. aureus culture from logarithmic growth phase was centrifuged at $4500 \mathrm{rpm}$ for $5 \mathrm{~min}$, washed with PBS, and resuspended in $1 \mathrm{~mL}$ of DMEM with $10 \%$ FBS. Bacterial clumps were removed by vertexing, and the bacteria were incubated with RAW264.7 cells at an MOI (multiplicity of infection) of 1 at $37^{\circ} \mathrm{C}$ for $2 \mathrm{~h}$. The culture medium was then replaced with fresh medium containing gentamicin $(50 \mu \mathrm{g} / \mathrm{mL})$, and the cells were incubated at $37^{\circ} \mathrm{C}$ for $60 \mathrm{~min}$ to have all extracellular bacteria killed. The cells were subsequently washed 3 times with PBS, treated with DASP $(450 \mu \mathrm{g} / \mathrm{mL})$ and different concentrations of chloramphenicol at $37^{\circ} \mathrm{C}$ for $24 \mathrm{~h}$ in DMEM (with $10 \% \mathrm{FBS}$ ). The treated infected cells were lysed with $0.5 \%$ Triton $\mathrm{X}-100$ for $15 \mathrm{~min}$, and the resulting suspensions were 
serially diluted before they were placed on agar plates for overnight incubation at $37^{\circ} \mathrm{C}$. The amount of intracellular S. aureus was quantified by counting the colonies. For each DASP/chloramphenicol combination, the experiment was carried out six times. 


\section{Characterization}

NMR Characterization of Intermediates and Polymers
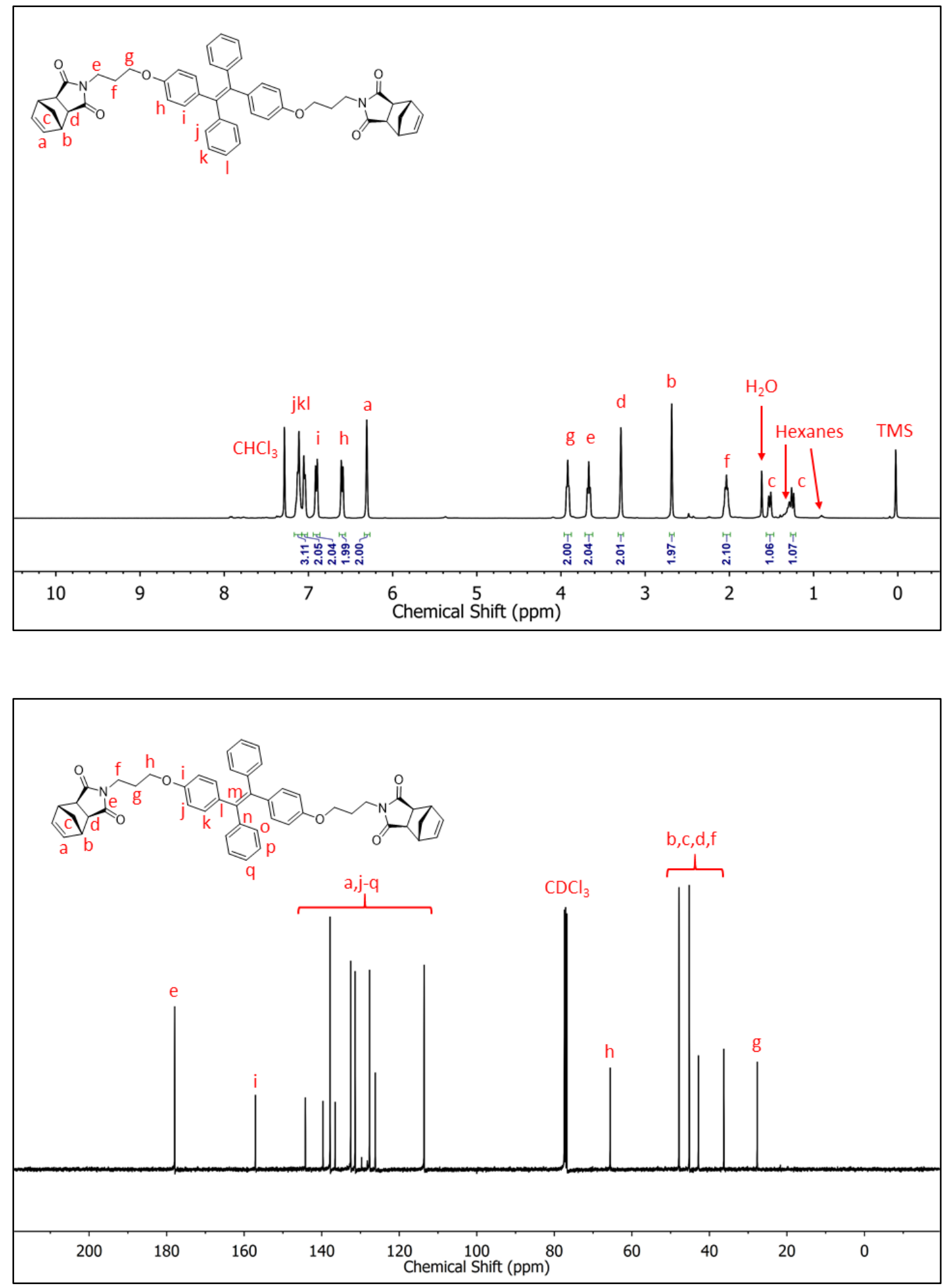

Figure S1. ${ }^{1} \mathrm{H}$ (top) and ${ }^{13} \mathrm{C}$ (bottom) NMR characterization of crosslinker 3 in $\mathrm{CDCl}_{3}$. 


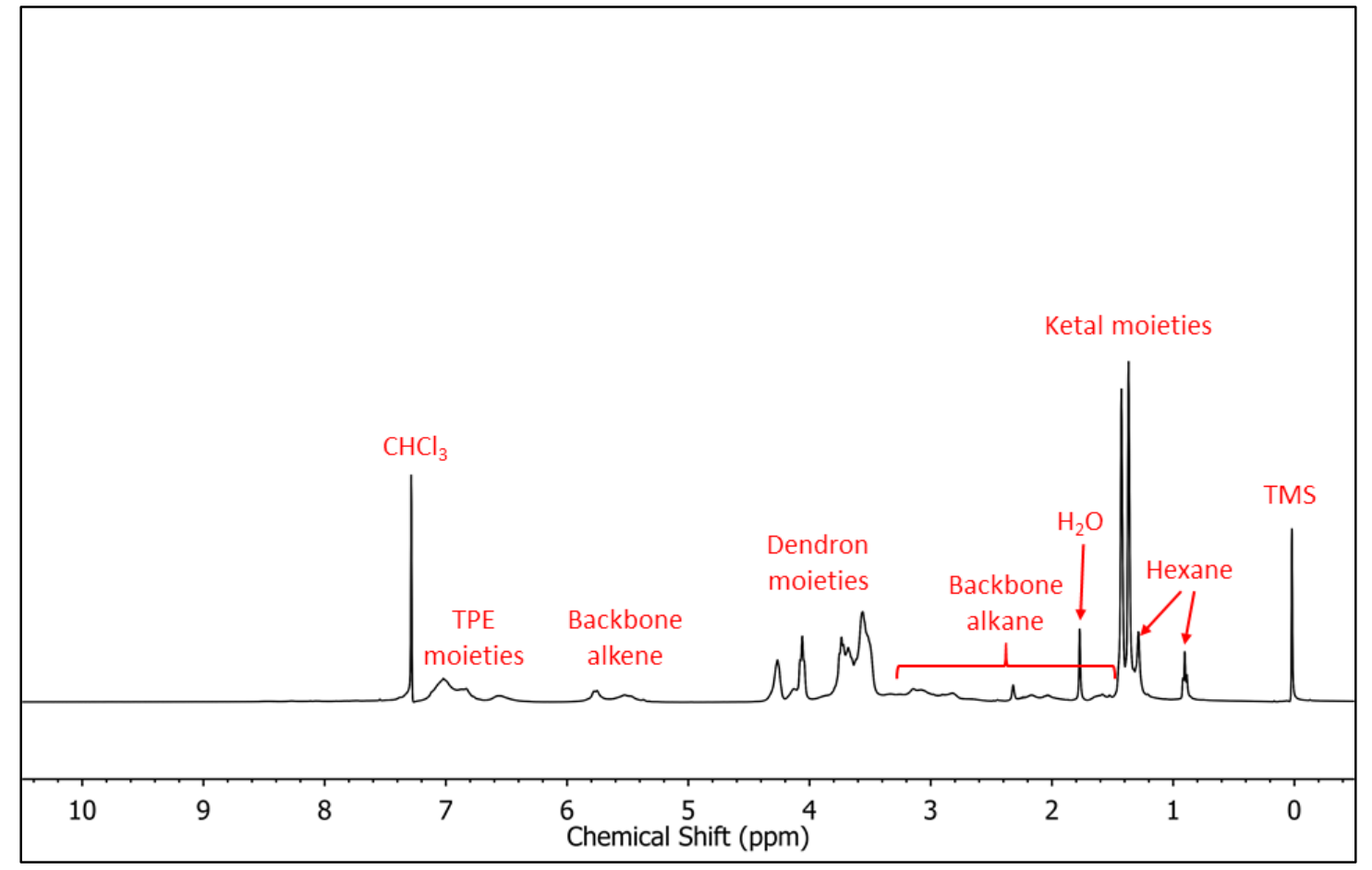

Figure S2. ${ }^{1} \mathrm{H}$ NMR characterization of ketal-protected DASP 4 in $\mathrm{CDCl}_{3}$.

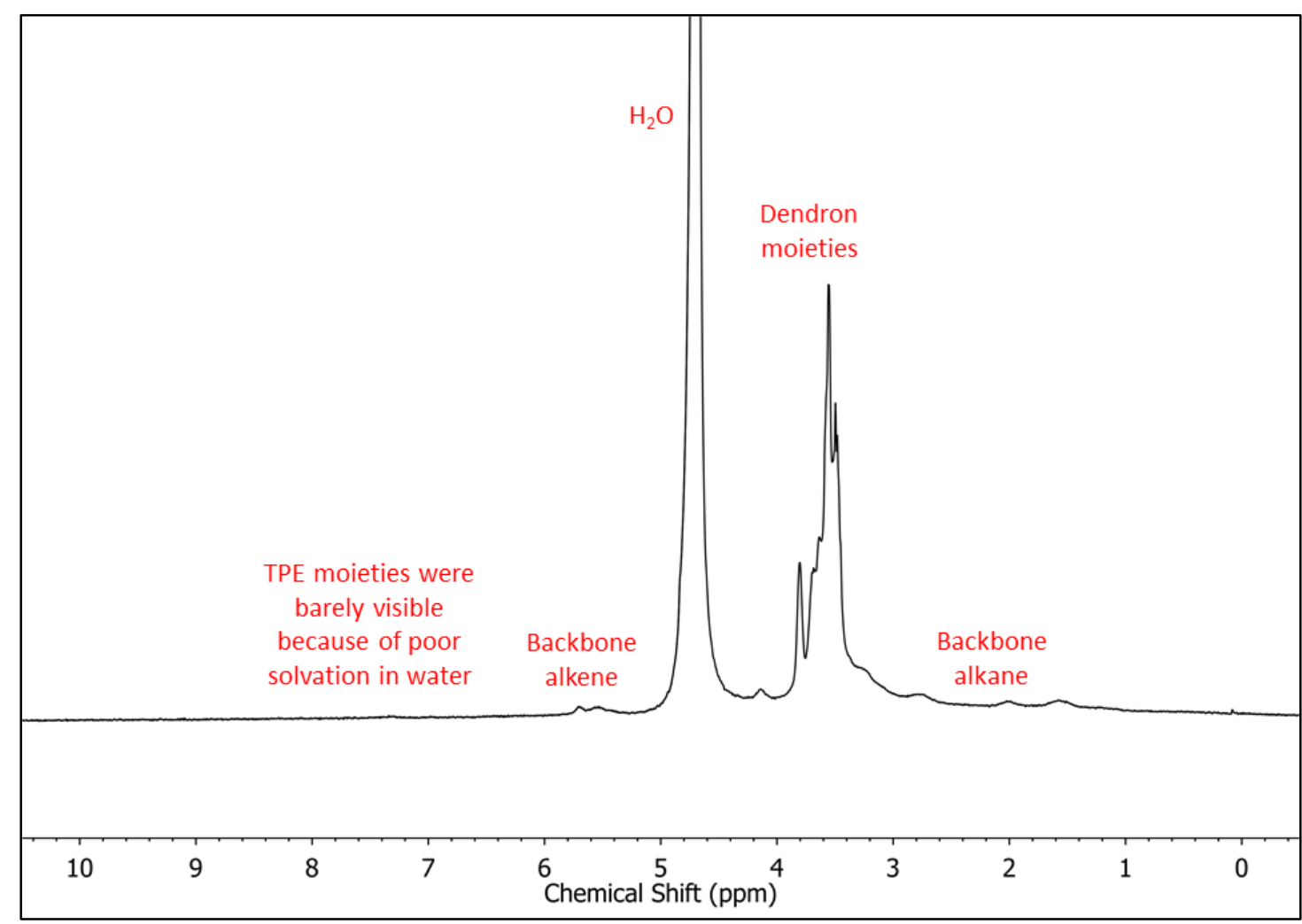

Figure S3. ${ }^{1} \mathrm{H}$ NMR characterization of DASP 5 in $\mathrm{D}_{2} \mathrm{O}$. 

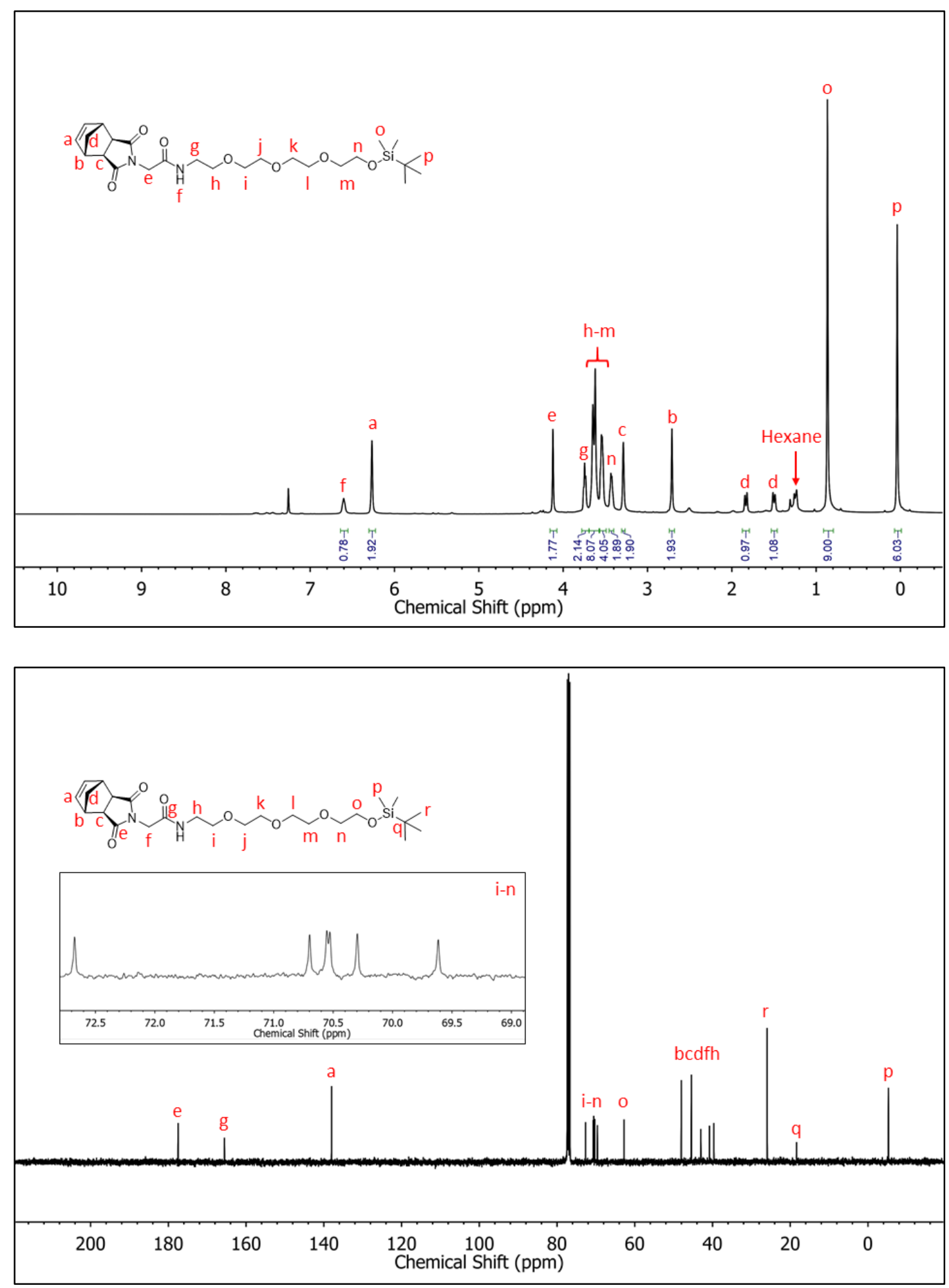

Figure S4. ${ }^{1} \mathrm{H}$ (top) and ${ }^{13} \mathrm{C}$ (bottom) NMR characterization of the TEG monomer (used for LASP synthesis) in $\mathrm{CDCl}_{3}$. 

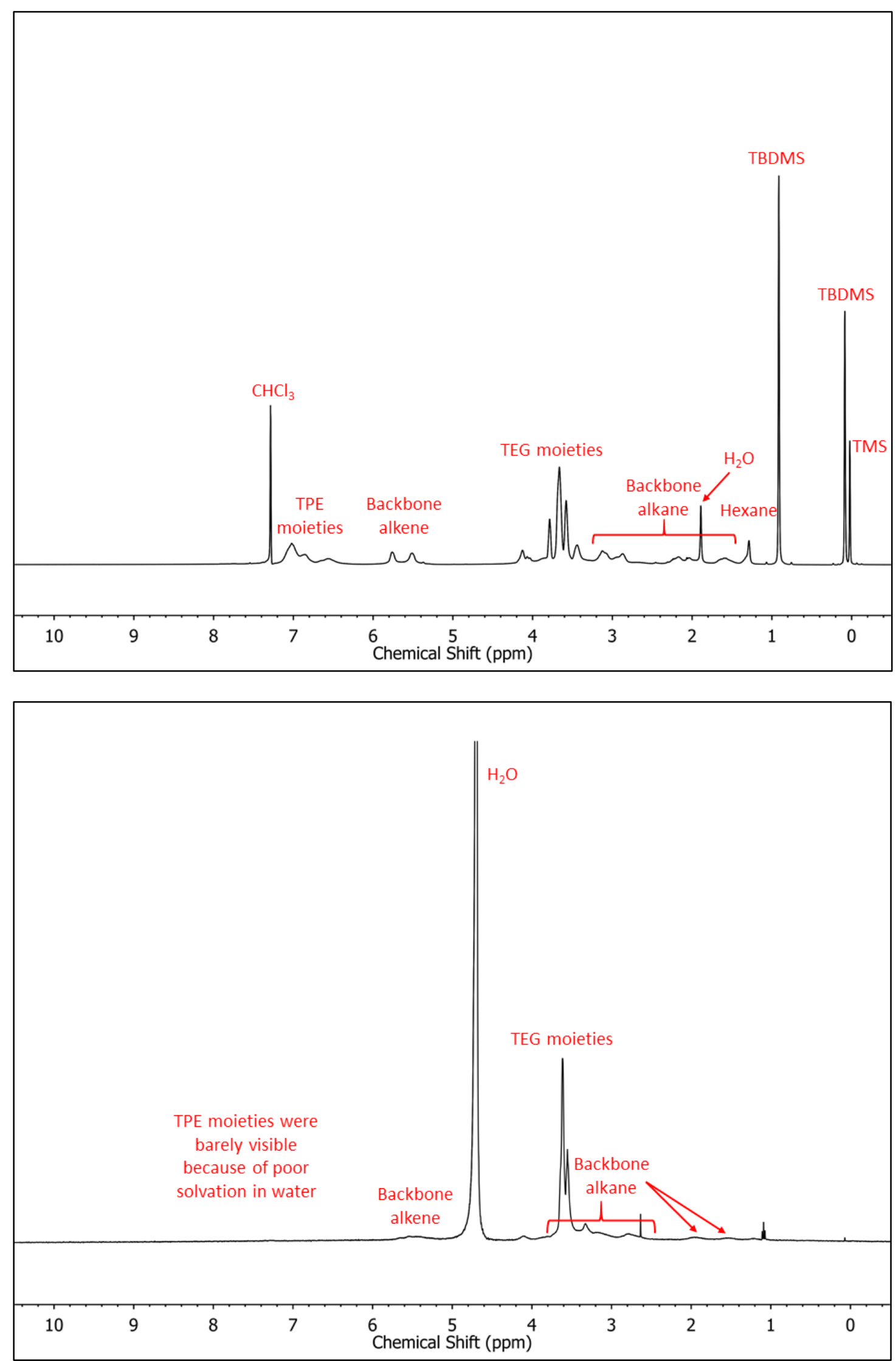

Figure S5. ${ }^{1} \mathrm{H}$ NMR characterization of TBDMS-protected LASP in $\mathrm{CDCl}_{3}$, and deprotected LASP in $\mathrm{D}_{2} \mathrm{O}$. 


\section{Transmission Electron Microscopy (TEM)}

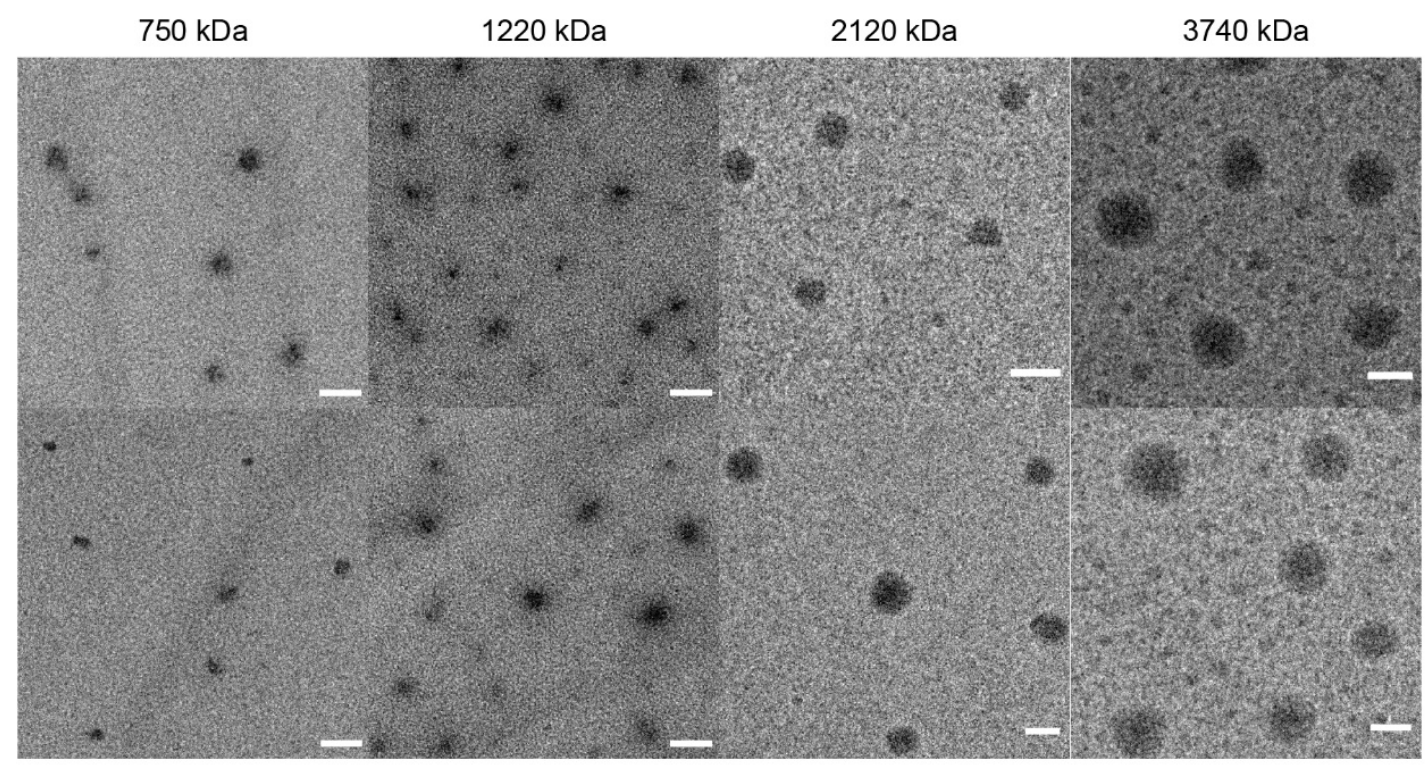

Figure S6. Additional TEM images of the DASP 5. Scale bar $=100 \mathrm{~nm}$. Condition for sample preparation was described in the Instruments section of this document.

\section{Additional GPC Data}
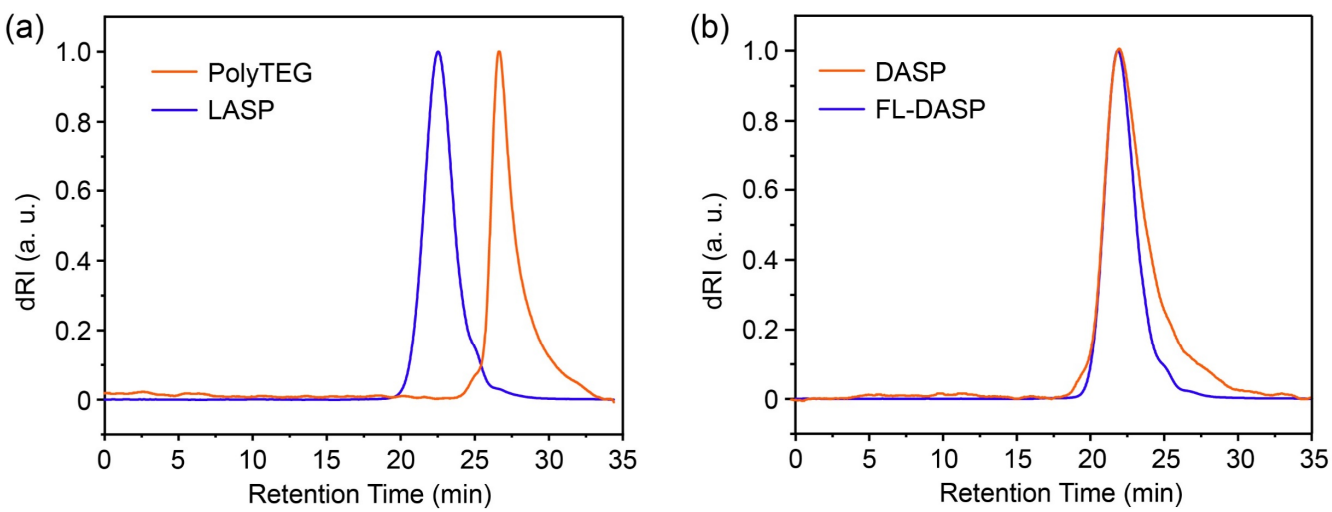

Figure S7. (a) GPC characterization of polyTEG arm and the corresponding LASP after crosslinking. (b) GPC characterization of DASP (Monomer : Crosslinker : Initiator $=$ 50:40:1) and FL-DASP ([PGD Monomer + FL Monomer] : Crosslinker : Initiator = [50+4]:40:1. 


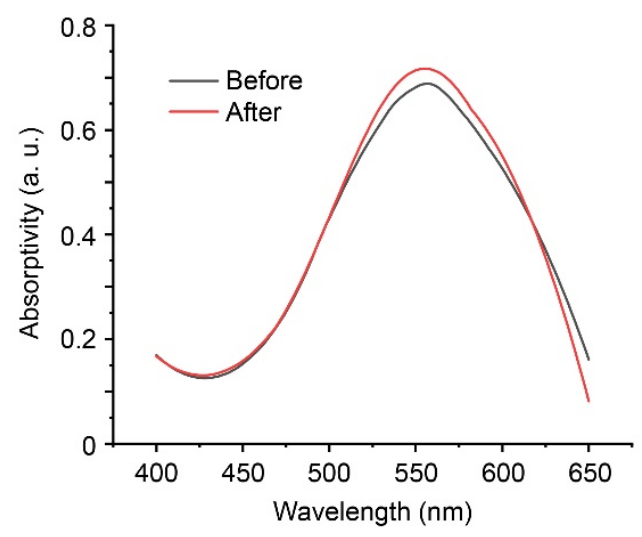

Figure S8. UV-vis spectra of a solution of DASP $750 \mathrm{kDa}$ encapsulating Nile Red, before and after dialysis. In our studies, DASP (containing Nile Red) was separated from free Nile Red by centrifugation. This separation method was effective for this system, as the solution did not show further decrease in Nile Red absorbance after further dialysis.

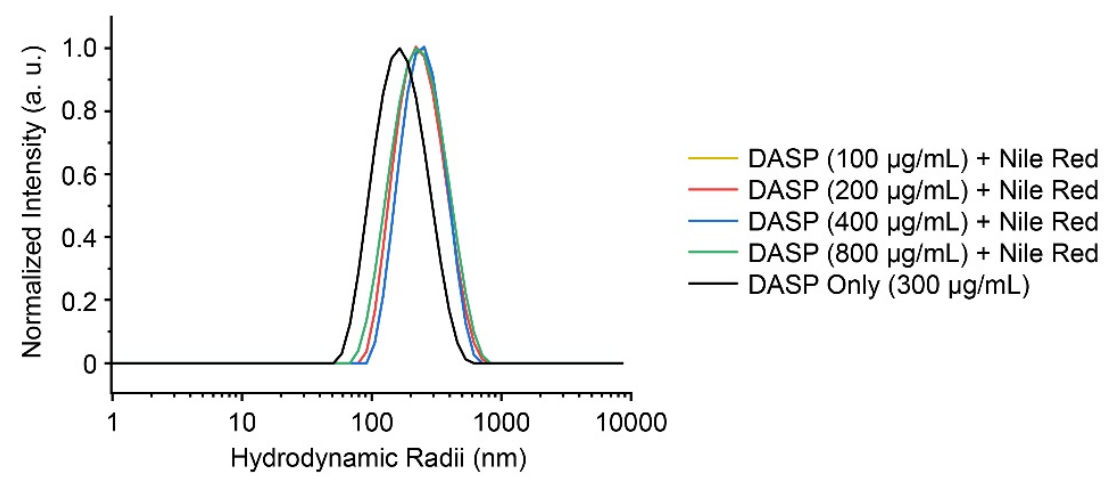

Figure S9. DLS analysis of free DASP $(750 \mathrm{kDa})$ and DASP with encapsulated Nile Red (maximized encapsulation). The measured diameter of DASP slightly increased with encapsulated dyes, but no significant aggregation was observed. 

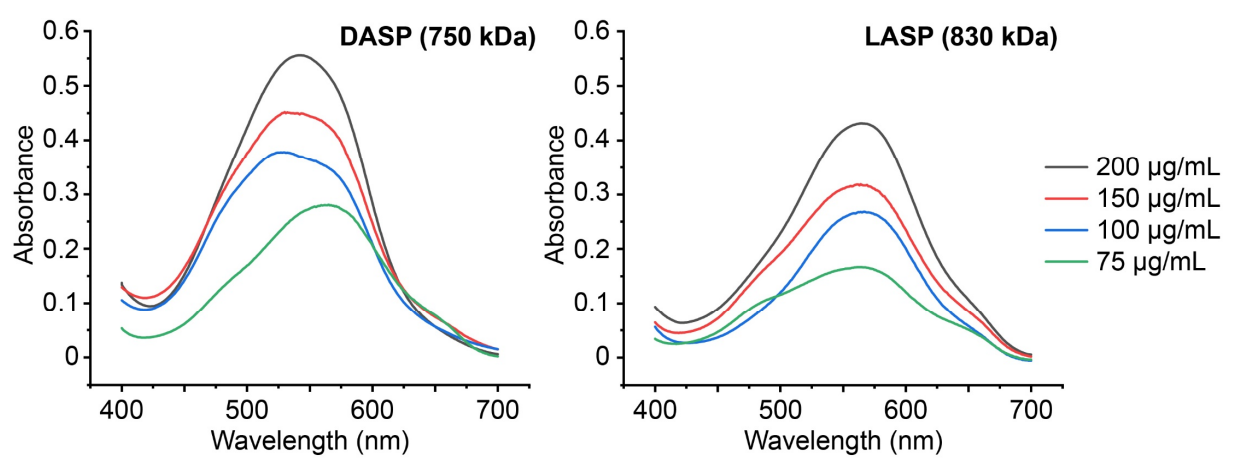

Figure S10. UV-vis spectra of DASP and LASP with encapsulated Nile Red. DASP showed higher encapsulation efficiency than LASP at all concentrations tested.
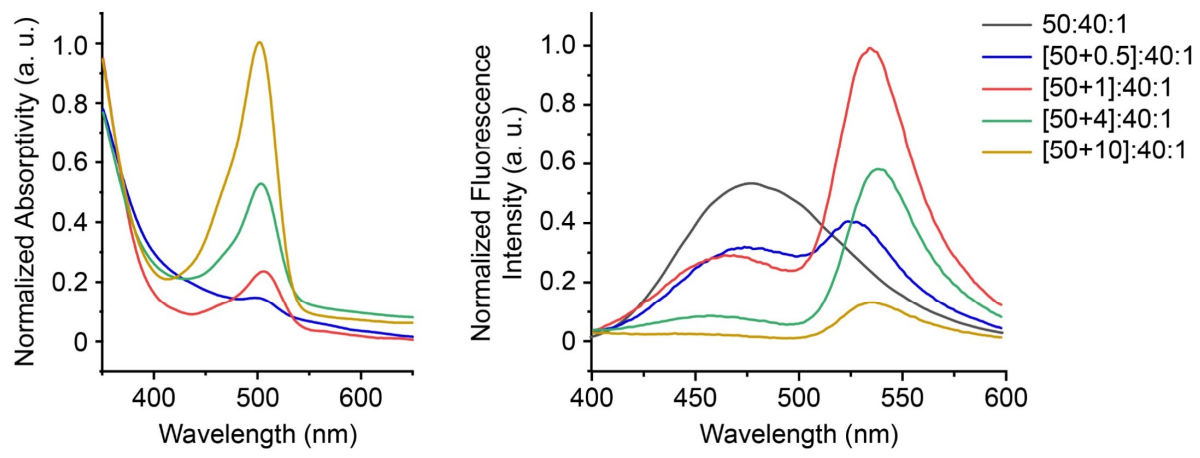

Figure S11. UV-vis (left) and fluorescence emission (right) spectra of FL-DASPs. The ratio indicated in the legend is in the format of [PGD Monomer + NB-FL] : Crosslinker : Initiator. The loading of fluorescein moiety increased as higher ratio of NB-FL was used in the preparation, according to UV-vis analysis.

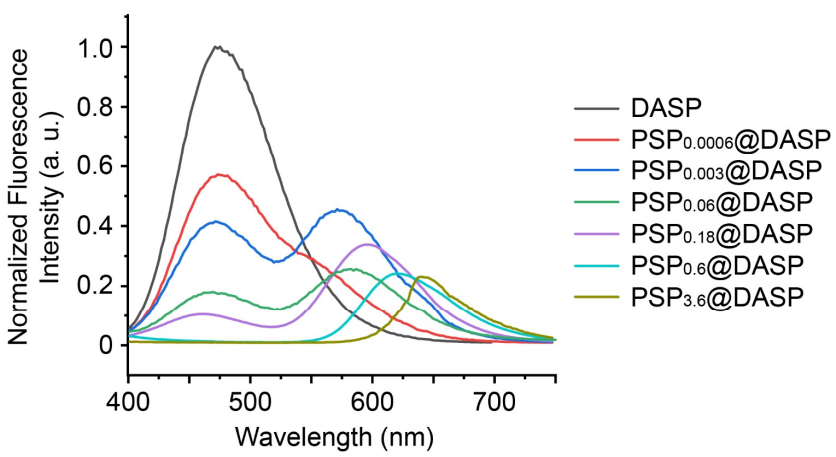

Figure S12. Fluorescence emission spectra of PSP@DASPs. The DASP used was the one with Monomer : Crosslinker : Initiator $=50: 40: 1$ ratio in the synthesis $(750 \mathrm{kDa})$. 


\section{$\underline{\text { Additional Confocal Microscope Images }}$}

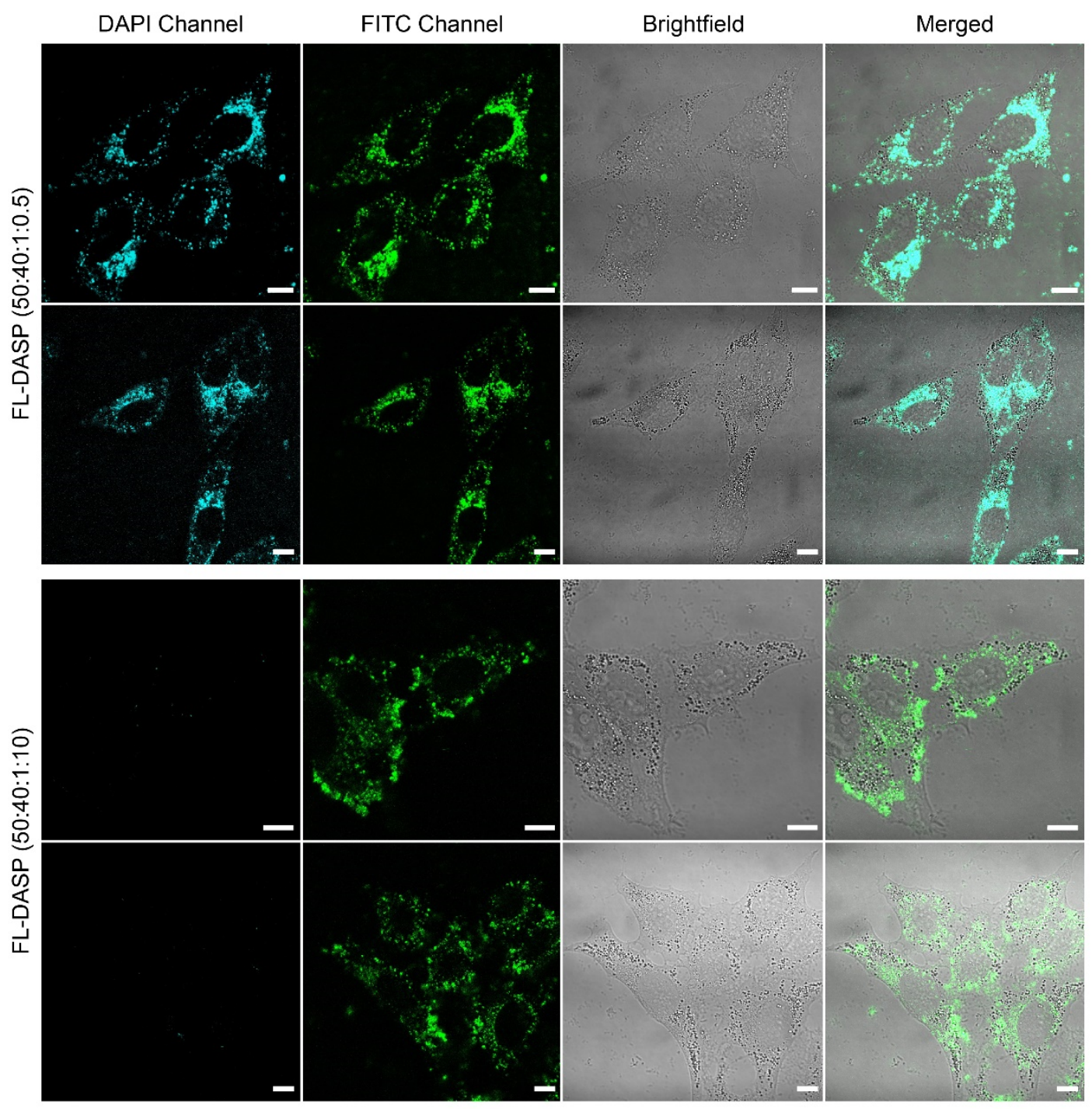

Figure S13. Confocal microscopic images of HeLa cells after being incubated with FLDASPs $(600 \mu \mathrm{g} / \mathrm{mL})$ with low or high fluorescein loadings. Numbers in the brackets indicate the ratio of dendron monomer 1 : crosslinker 3 : initiator 2: fluorescein monomer FL-NB used in the syntheses. Higher loading of fluorescein moiety in the DASP scaffold increased FRET efficiency, converting the blue-emission DASPs to blue-green dichromatic DASPs, then to green-emission DASPs. Scale bar $=10 \mu \mathrm{m}$. 


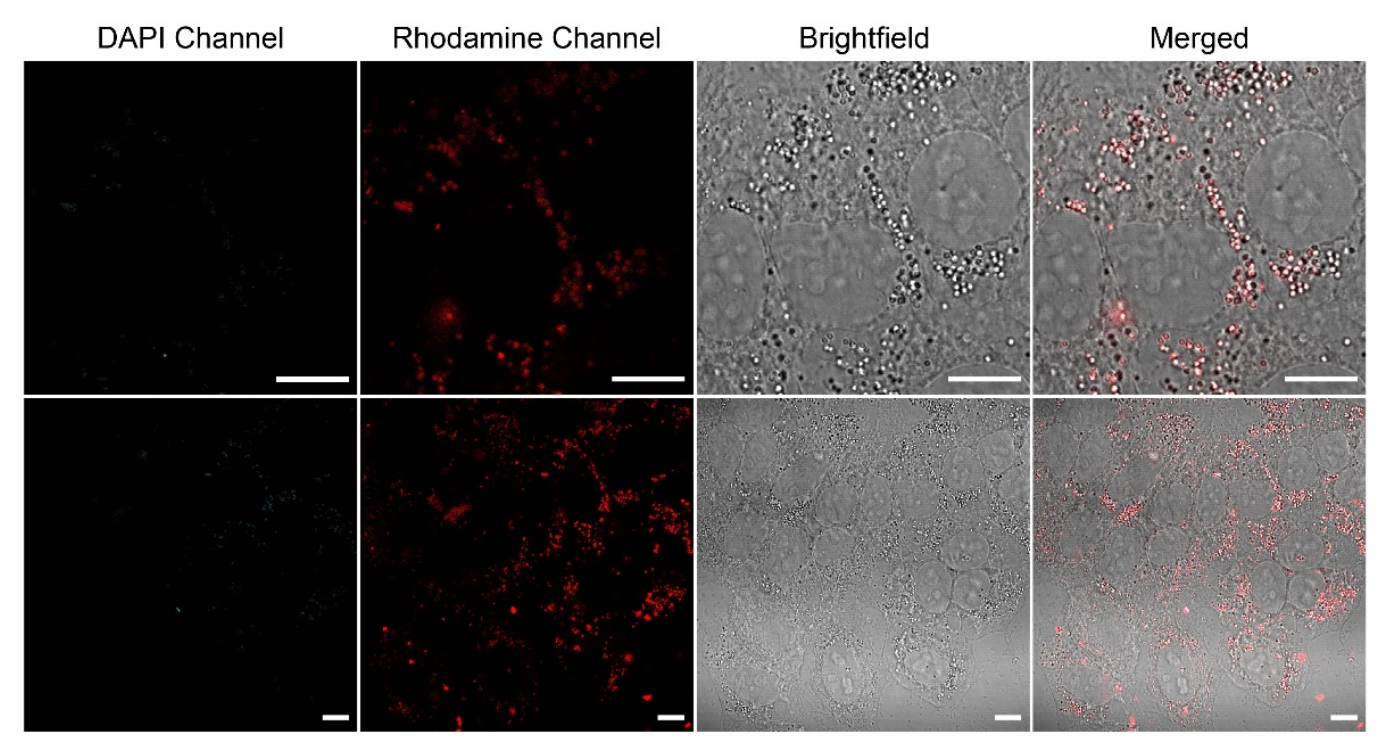

Figure S14. Confocal microscopic images of HeLa cells after being incubated with PSP3.6@DASPs (400 $\mu \mathrm{g} / \mathrm{mL})$. Through FRET, the DASPs could have very large Stokes shift and narrow fluorescent emission in the far-red range. Scale bar $=10 \mu \mathrm{m}$. 




Figure S15. Confocal microscopic images of HeLa cells after being incubated with DASP 5 of various sizes. Incubation time: $24 \mathrm{~h}$. [DASP 5] $=1 \mathrm{mg} / \mathrm{mL}$. Cell uptake of 5 clearly diminished as its molecular weight increased. Scale bar $=10 \mu \mathrm{m}$. 


\section{Cytotoxicity Study}

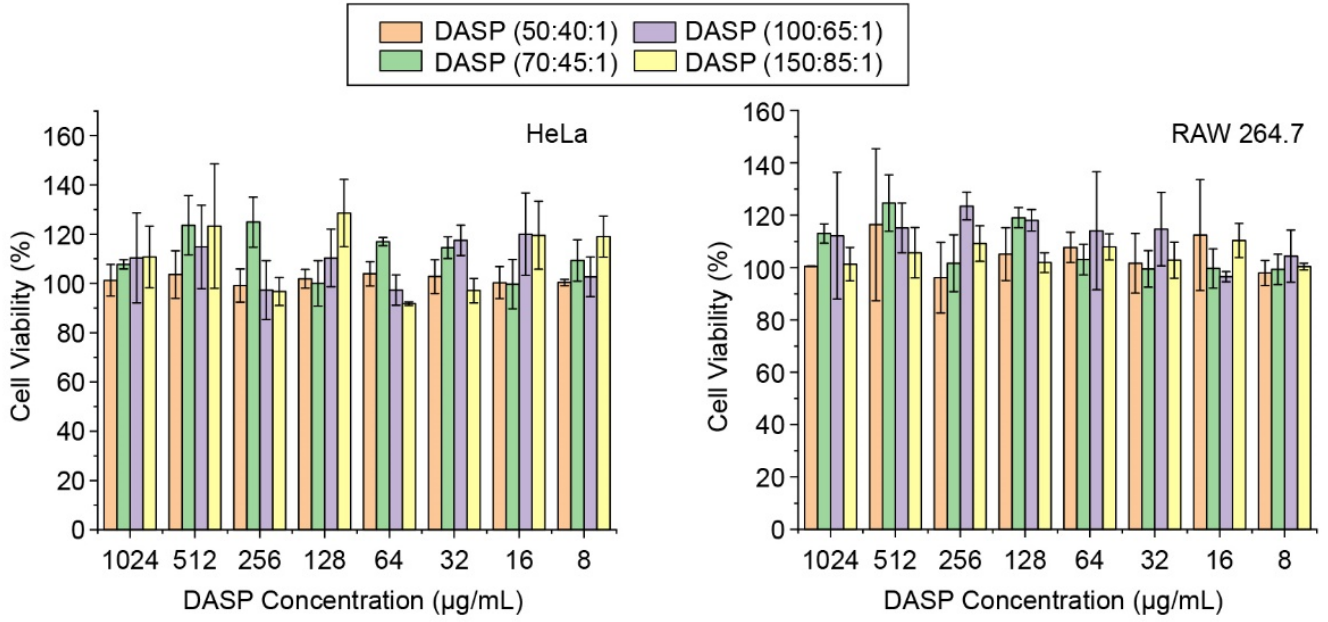

Figure S16. Neutral Red uptake assay results of DASP 5 with HeLa or RAW 264.7 cells. 
$\underline{\text { Mass Spectra }}$

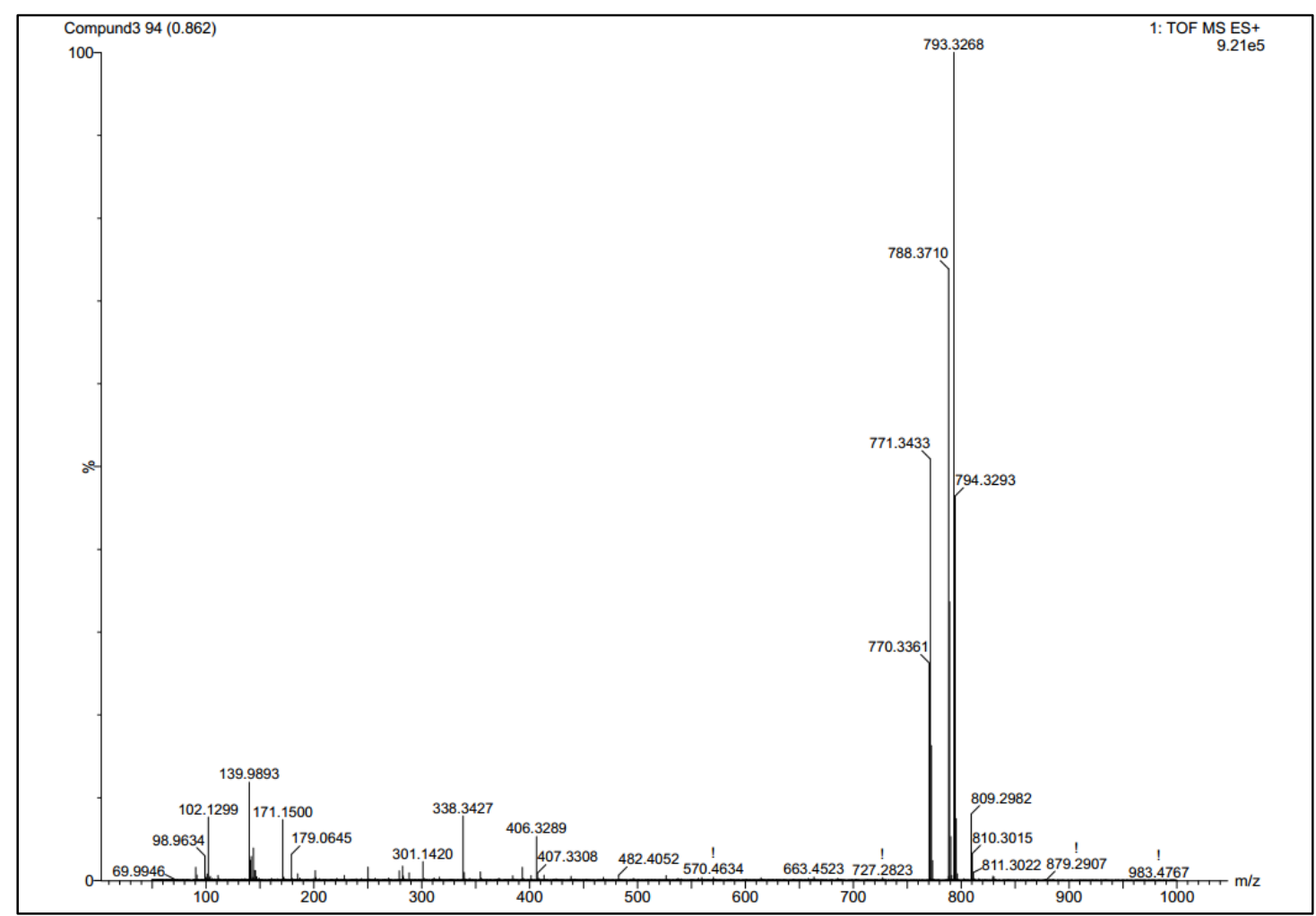

Figure S17. High resolution ESI mass spectrum of crosslinker 3.

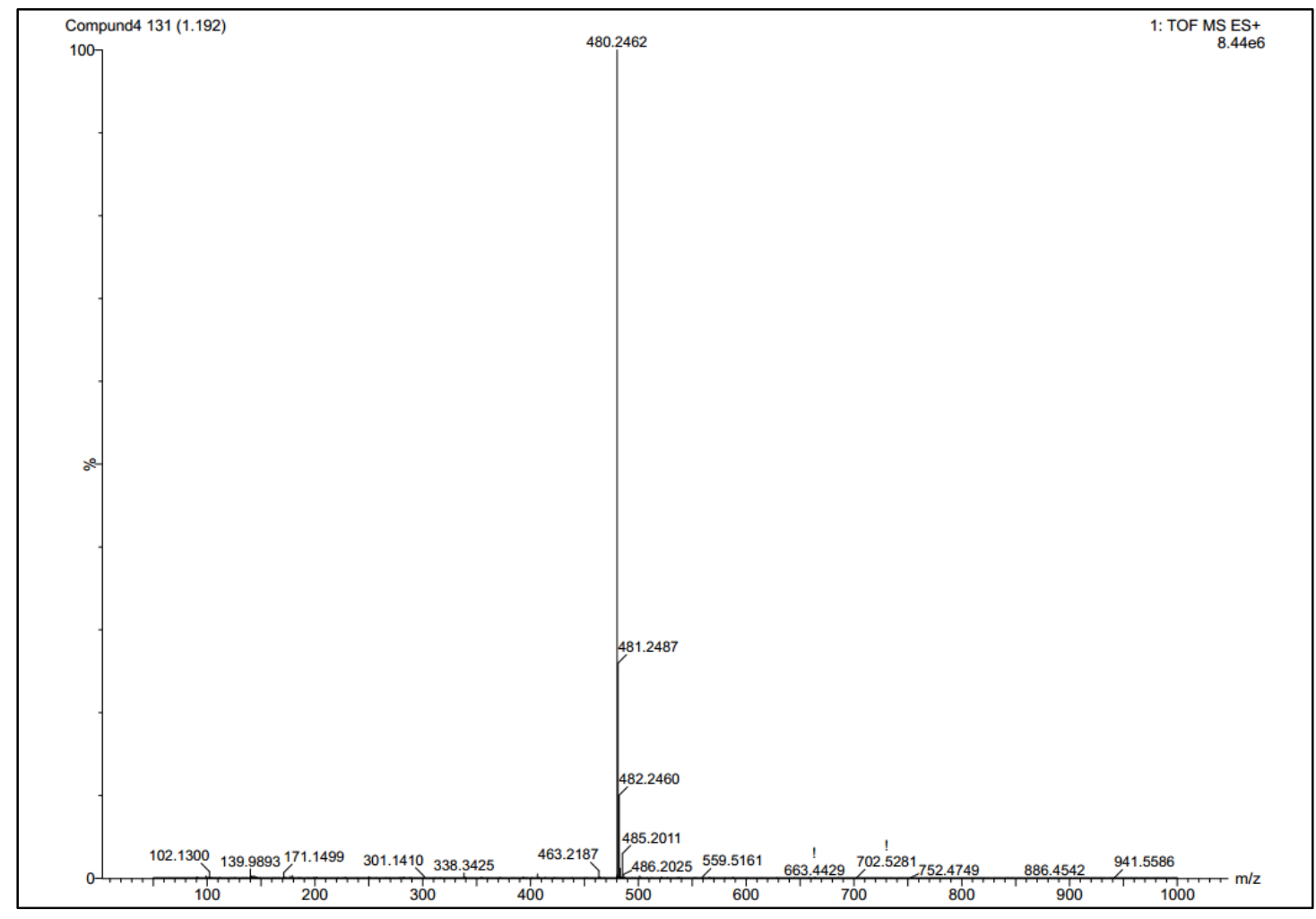

Figure S18. High resolution ESI mass spectrum of TsO-TEG-OTBDMS. 


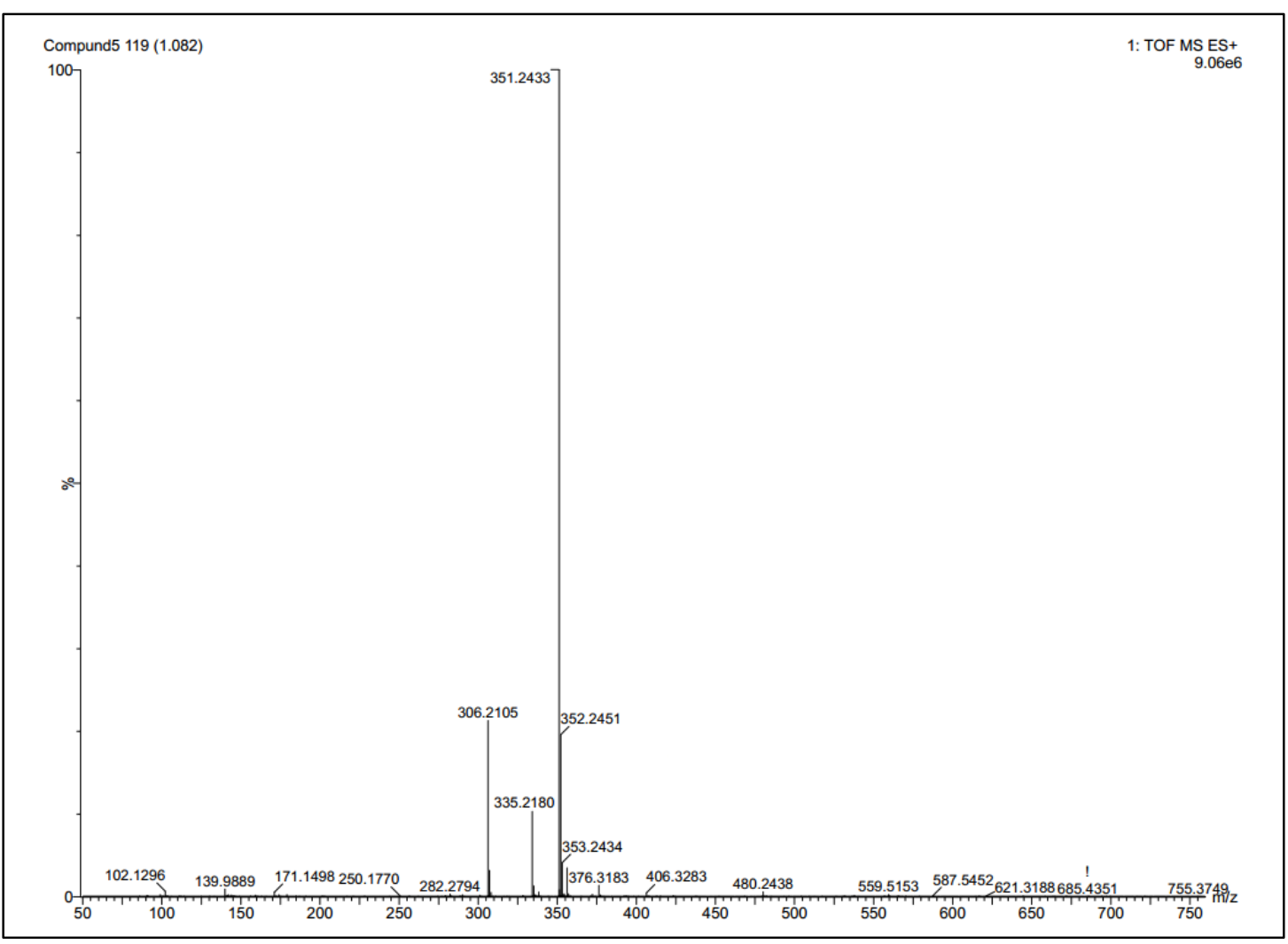

Figure S19. High resolution ESI mass spectrum of $\mathrm{N}_{3}$-TEG-OTBDMS.

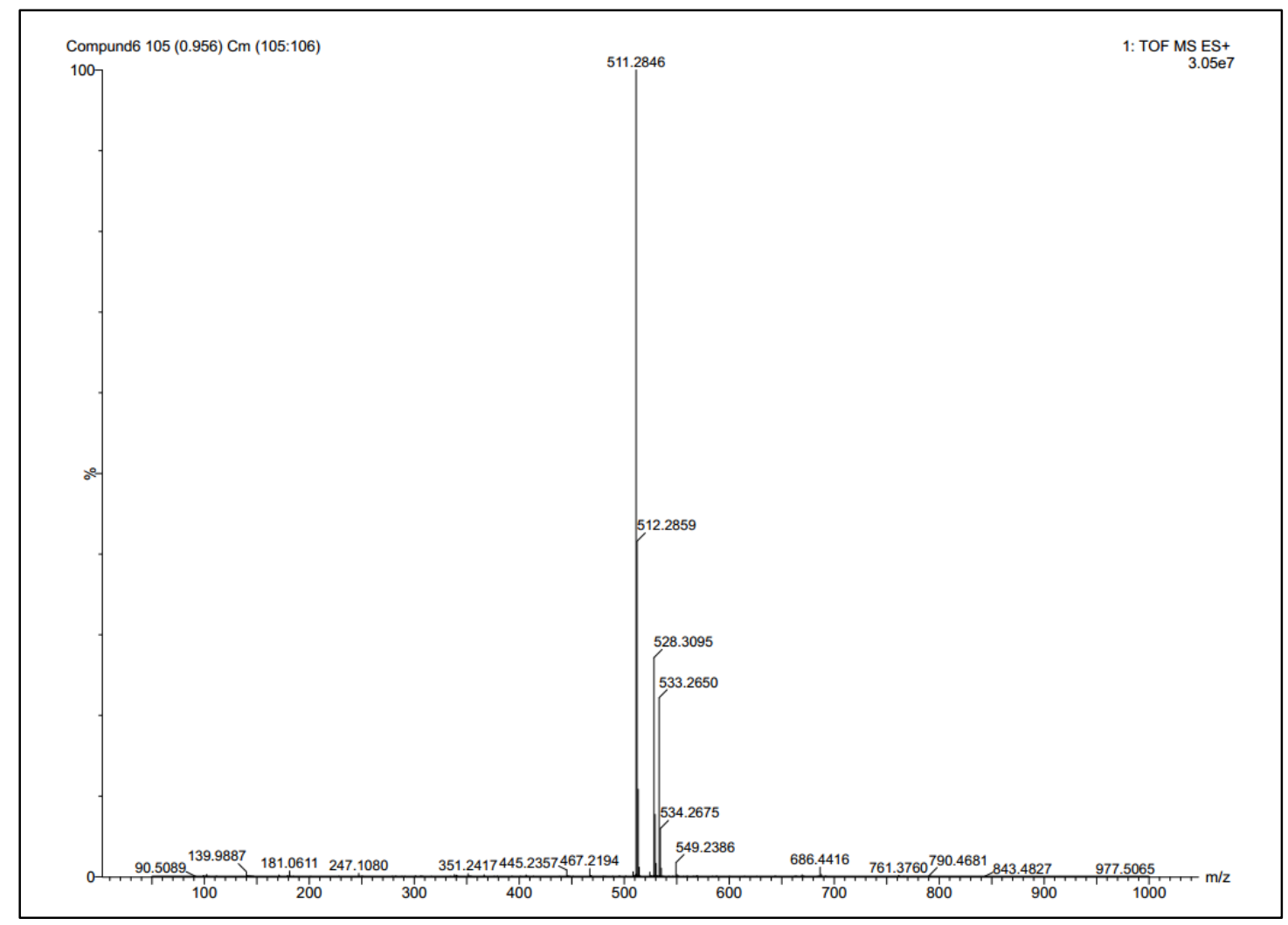

Figure S20. High resolution ESI mass spectrum of the TEG monomer. 


\section{Summary Tables}

Table S1. Characterization results and quantum yields of DASPs of different sizes. Fluorescence of these DASPs were from fAIE of tetraphenylethylene moieties at the cores.

\begin{tabular}{cccccc}
\hline $\begin{array}{c}\text { Dendron monomer : } \\
\text { Initiator : Crosslinker }\end{array}$ & $\begin{array}{c}\boldsymbol{M}_{\mathbf{n}} \text { Before } \\
\text { Ketal Removal } \\
\left(\mathbf{1 0}^{5} \mathrm{Da}\right)\end{array}$ & $\boldsymbol{\theta}$ & $\begin{array}{c}\text { Measured } \\
\boldsymbol{d n} / \boldsymbol{d c}\end{array}$ & $\begin{array}{c}\text { Zeta } \\
\text { Potential } \\
(\mathbf{m V})\end{array}$ & $\begin{array}{c}\text { Quantum } \\
\text { Yield }(\%)\end{array}$ \\
\hline $50: 1: 40$ & 7.5 & 1.31 & 0.077 & -0.60 & 0.38 \\
$70: 1: 45$ & 12.2 & 1.27 & 0.073 & 0.23 & 0.24 \\
100:1:65 & 21.2 & 1.25 & 0.069 & 0.70 & 0.30 \\
150:1:85 & 37.4 & 1.22 & 0.052 & -0.53 & 0.30 \\
\hline
\end{tabular}

Table S2. Quantum yields of DASPs with covalently attached fluorescein moieties. Quantum yields were calculated based on the emission of fluorescein moieties only at TPE's excitation wavelength.

\begin{tabular}{cc}
\hline Dendron monomer : Fluorescein monomer : Initiator : Crosslinker & $\begin{array}{c}\text { Quantum Yield } \\
\text { (\%) }\end{array}$ \\
\hline $50: 0.5: 1: 40$ & 32 \\
$50: 1: 1: 40$ & 51 \\
$50: 2: 1: 40$ & 31 \\
$50: 4: 1: 40$ & 26 \\
$50: 6: 1: 40$ & 17 \\
$50: 8: 1: 40$ & 11 \\
$50: 10: 1: 40$ & 7 \\
$50: 0: 1: 40$ & 38 (TPE) \\
\hline
\end{tabular}


Table S3. Quantum yields of DASPs (750 kDa) with non-covalently encapsulated PSP moieties. Quantum yields were calculated based on the emission of PSP moieties only (wavelengths indicated in the table), at TPE's excitation wavelength.

\begin{tabular}{ccc}
\hline Loading of PSP Fluorophore & Emission Wavelength $(\mathbf{n m})$ & Quantum Yield (\%) \\
\hline 0.003 & 575 & 14 \\
0.06 & 580 & 7.7 \\
0.18 & 595 & 10 \\
0.3 & 610 & 6.9 \\
0.6 & 625 & 6.8 \\
1.8 & 625 & 6.9 \\
3.6 & 645 & 7.3 \\
0 & 475 & 38 (TPE) \\
\hline
\end{tabular}

Note: TPE's emission was fully quenched when PSP loading was 0.6 and above. 